\title{
RECENZJA KSIĄŻKI MALGORZATY STĘPNIK OUTSIDERZY, MISTYFIKATORZY, ESKAPIŚCI W SZTUCE XX WIEKU. STUDIUM POSTAW TWÓRCZYCH, WYDAWNICTWO UNIWERSYTETU MARII CURIE-SKLODOWSKIEJ, LUBLIN 2016
}

Autorka - teoretyk i krytyk sztuki, adiunkt w Instytucie Sztuk Pięknych Uniwersytetu Marii Curie-Skłodowskiej w Lublinie - zastosowała w swoich analizach interdyscyplinarne instrumentarium badawcze, implementując wiedzę z zakresu teorii i socjologii sztuki oraz estetyki, można zatem mówić tutaj o triangulacji teoretycznej. Wielość perspektyw, pomocnych przy interpretacji danych (m.in. biografizm, psychoanaliza), to jeden $\mathrm{z}$ atutów tekstu opracowanego przez panią Stępnik. Znajomość i biegłość poruszania się w kilku dziedzinach sztuki (literatura, film, fotografia, malarstwo) pozwalają jej na holistyczne spojrzenie na światowy artworld. Odwołania do różnych kręgów kulturowych, do licznych symboli, archetypów i mitów, zdradzają wytrawnego analityka, wyposażonego w pogkębioną wiedzę historyczną i antropologiczną.

Narracja ukazuje nie tylko kompetencje, ale i artystyczną duszę Autorki (łatwo identyfikowalny styl, odbiegający od sztywnych reguł naukowego dyskursu). Czytelnik-malkontent mógłby narzekać na pewną impresyjność i migotliwość stylu, na typowo eseistyczny charakter opracowania (m.in. brak pogłębionej refleksji metodologicznej). Czytelnik przychylnie nastawiony dostrzeże natomiast pasję i erudycję Interpretatora, a brak precyzji czy dyscypliny analitycznej (liczne dygresje) przesłoni mu odkrywanie wraz z Autorką nowych przestrzeni artystycznych, nieznanych jeszcze w Polsce faktów dotyczących zaprezentowanych w książce outsiderów, mistyfikatorów i eskapistów. Podążanie za Autorką jest de facto wejściem do nowego uniwersum, nieco rozedrganego, ale tym bardziej pasjonującego. Znajdujemy w tym świecie fikcyjne postaci, wyimaginowane historie, „partykularne zawłaszczenia”, mistyfikacje i twórcze inkarnacje. Autorka

* Katedra Socjologii Sztuki i Edukacji, Instytut Socjologii, Wydział Ekonomiczno-Socjologiczny Uniwersytetu Łódzkiego, e-mail: emilia.zimnica@onet.eu 
przyznaje, że bohaterów jej książki dzieli dystans czasu i geograficznej przestrzeni, ale „łączy jednak specyficzne podejście do prawdy i do własnej prywatnej historii. Jest w ich twórczym oeuvre coś, co pozwolę sobie nazwać logika maski $i$ wcielenia bądź też wirtualnościa mistyfikacji. Obrane przez nich strategie doskonale wpisują się w kulturę wszechpanującej symulacji [...]" (s. 19). Wszystkim twórcom, którym poświęciła uwagę, przypisała „tendencje outsiderskie i eskapistyczne", nazwała ich duchowymi (i nie tylko) emigrantami. Interesujące jest w pracy Stępnik budowanie intertekstualności, przywoływanie klasycznych wersji mitów i ich aktualizacji (także w kulturze popularnej).

Ważne wydaje się pytanie o źródła twórczych mistyfikacji w kulturze współczesnej. Małgorzata Stępnik upatruje przyczyn w rozpadzie i fragmentaryzacji świata (Jean-François Lyotard i zmierzch „wielkich narracji”, Weberowskie „odczarowanie świata”, „rozpad sfery społecznej” ogłoszony przez Jeana Baudrillarda). Tendencje eskapistyczne i mistyfikatorskie mają być zatem antidotum na niepewną, niestabilną rzeczywistość, niedającą poczucia pewności i niekwestionowanego sensu. „Każda inteligentna mistyfikacja oznacza tworzenie nowej, sensownej rzeczywistości zamiast dawnego porządku, który się rozpadł, płynnego i pozbawionego centrum, reanimowanego jedynie w społecznych mitach" (s. 11). Autorka opracowania odrzuca a limine (czy całkiem słusznie?) eksplikacje $\mathrm{z}$ dziedziny psychopatologii. Ucieczka w wyimaginowane uniwersum może być de facto inteligentną grą, przemyślaną intelektualną strategią twórczą, może też być efektem zaburzeń osobowości neurotyków (a przecież według Freuda są nimi wszyscy artyści).

W książce znajdujemy opis twórczych strategii stosowanych przez omawianych artystów (swoją drogą nie do końca wiemy, dlaczego akurat oni spośród wielu innych twórców spełniających kryterium zawarte w tytule rozprawy zostali wybrani przez Autorkę), owe strategie mają wspólny mianownik (,eksterytorialność", tworzenie wyimaginowanych przestrzeni artystycznych). Niemniej każdy z bohaterów, nazwanych tutaj „włóczęgami międzyjęzykowych przestrzeni”, ma swoją indywidualność i każdy we właściwy sobie sposób dokonuje transgresji, przekroczenia i wewnętrznej bądź rzeczywistej ucieczki od tzw. zwykłego życia. Nie bez znaczenia jest fakt, że książkę otwiera esej poświęcony figurze Golema, glinianego potwora, który ożywa pod wpływem kreacyjnej mocy Słowa (na kartach książki spotykamy się też z mitem Dybuka, Narcyza czy Meduzy). Golem, jak pisze Stępnik, ,stanowi figurę uniwersalną, metaforę dzieła zrodzonego z cudownie zuchwałej i (niemal) nieograniczonej twórczej inteligencji” (s. 16).

Pierwszym artystą, któremu przygląda się Autorka, jest Ronald B. Kitaj (1932-2007), twórca Pierwszego manifestu diaspory. Trzeba podkreślić, że „diasporyzm jest kategorią odnoszącą się do twórczej postawy, do nomadycznej, wygnańczej kondycji artystów nowoczesnych, niekoniecznie natomiast do ich etnicznego pochodzenia" (s. 60). Kitaj, amerykański malarz żydowskiego pochodzenia, związany z brytyjskim artworld $\mathrm{em}$, w swoich tekstach porusza problemy 
multikulturowości i postkolonializmu, a tematem szczególnie go zajmującym jest procesualna tożsamość artysty - podróżnika, wędrowca, wygnańca, tułacza. Niezadomowienie, twórczy exodus ma walor kreatywny, warunkuje „zachowanie myśli płynnej i żywej jak rtęć" (s. 57). Jednocześnie twórczość diasporystów naznaczona jest nostalgią i melancholią.

Kolejna artystka, Eleanor Antin (ur. 1935), eksperymentuje z własną tożsamością, m.in. poprzez tworzenie swojego „Zwielokrotnionego portretu” (fotografia z 1973 roku The Two Eleanors), poprzez założenie męskiego kostiumu i przyklejenie sobie brody (metamorfoza Antin w Króla kalifornijskiego miasteczka Solana Beach). Dzięki „sfabrykowaniu” amerykańskiej artystki, Czarnej Balleriny z Ballets Russes Diagilewa, poddaje refleksji takie kategorie jak Jewishness Blackness Womanness, Otherness. Jej sfilmowane akcje performatywne zawierają liczne feministyczne i rasistowskie wątki. Najważniejszym dziełem Antin - zdaniem Stępnik - jest film Człowiek bez świata, obraz nawiązujący do tradycji przedwojennego kina jidysz, „odzwierciedlającego i w równym stopniu mitologizującego zbiorowe doświadczenia Żydów wschodniej Europy" (s. 95).

Z kolei Maya Deren, czyli Eleonora Derenkowska (1917-1961), przedstawicielka amerykańskiej awangardy filmowej, tancerka i choreografka, antropolożka, koncentruje swoją twórczość wokół motywu lustra, lustrzanego odbicia i sobowtóra. Stępnik odnotowuje fascynację artystki haitańską kulturą voodoo i patrzy na artystyczne działania artystki z perspektywy psychoanalitycznej. Inklinacje Deren do zakładania masek i tworzenia sobowtórów zestawia z podobnymi tendencjami twórczymi (fotograficznymi autoportretami) Claude Cahun (18941954) i zwielokrotnionymi twarzami Cindy Sherman (ur. 1954).

Zdaniem Stępnik w formułę twórczej mistyfikacji znakomicie wpisuje się Roee Rosen (ur. 1963), izraelski artysta multidyscyplinarny, pisarz i reżyser filmowy. Powołując do życia artystkę Justine Frank, nadał jej etykietkę „surrealizującej malarki, skandalistki i pornografki” (s. 45). Na potrzeby uwiarygodnienia jej istnienia stworzył wiele dzieł - obrazów, fotografii i tekstów literackich.

Kolejny bohater książki, Edward James (1907-1984), wyczarował rajski ogród w Meksyku (Las Pozas), czyli projekt architektoniczny, w ramach którego skonstruował betonowe kwiaty i inne obiekty rzeźbiarskie. Jak pisze Autorka, „ów betonowy Eden odwzorowuje nielinearną, illogiczną i otwartą strukturę marzenia sennego" (s. 9) i stanowi niewątpliwie sztuczną enklawę, miejsce ucieczki od realności i zwyczajności.

Outsiderką i mistyfikatorką była też Maria Komornicka (1876-1949), polska pisarka młodopolska, tłumaczka i krytyczka literacka, która uznała się za mężczyznę (wcieliła się w Piotra Własta, Odmieńca). Jej metamorfoza polegała nie tylko na używaniu nowego nazwiska, ale i na noszeniu męskiej garderoby, paleniu fajki etc. Jej ekstrawaganckie zachowanie uznane zostało za przejaw choroby psychicznej, toteż artystka wiele lat spędziła w szpitalach i sanatoriach. 
W intymne muzeum wyobraźni przenosi nas również Zuzanna Rabska (1888-1960), poetka, jak pisze Stępnik, ,intelektualnych wzruszeń”. Outsiderka emigruje wewnętrznie w świat książek i obrazów. Jest też podróżniczką, która pod wpływem spotkań ze sztuką europejską tworzy ekfrazy, strofy poetyckie poświęcone kanonicznym dziełom malarstwa.

Ciekawą postacią, która zamyka prezentację postaw twórczych, jest Piotr Szmitke (1955-2013), twórca doktryny metawerystycznej i założyciel Niepodległej Monarchii Metawery (rzeczywisty emigrant, obcy na francuskiej ziemi). Wykreował on alternatywną rzeczywistość, świat pozoru i fikcji, ze sztucznie stworzonymi autorytetami i idolami, świat nieistniejących zasobów. Pokazał mechanizmy stwarzające artystów (krytycy i ich rola opiniotwórcza, konsekrująca) i paradoksy funkcjonowania systemu artystycznego (spreparował życiorysy twórców, krytyków i naukowców; uwiarygodnił ich zawodową tożsamość stosownym opisem). Mistyfikacja, symulacja, pastisz - mimo pozoru zabawy i gry z odbiorcą - mają głębszy sens, pokazują procesy urealniania nierzeczywistości w czasach dominacji cyberkultury i postępującej wirtualizacji. Warto dodać, że Szmitke jest artystą multidyscyplinarnym, autorem metawerystycznej opery (wystawionej w Operze Śląskiej w Bytomiu), filmu Zbrodnia Ikara, twórcą multimedialnej kurtyny Teatru Śląskiego w Katowicach.

Na koniec trzeba odnotować, że książkę, która liczy 289 stron i składa się z dziewięciu rozdziałów, wzbogacają kolorowe ilustracje nawiązujące do zaprezentowanych twórców i ich dzieł. Warto podkreślić oczytanie pani Stępnik w światowej literaturze przedmiotu i jej własne thumaczenia (starannie opracowane przypisy, bogata bibliografia, która obejmuje kilkanaście stron). W książce Małgorzaty Stępnik, której patronuje Jean Baudrillard i jego Symulacja i symulakry, trzeba się rozsmakować (nie jest to „miłość od pierwszego kontaktu”). I naprawdę warto. 